\title{
Satisfaction degree of English teachers of Preschool and Primary Education in the Principality of Asturias ${ }^{1}$
}

\author{
Alberto Fernández-Costales ${ }^{*}$ ) y Xosé Antón González-Riaño $\left(^{*}\right)$ \\ $\left.{ }^{*}\right)$ University of Oviedo - Spain
}

\begin{abstract}
This paper analyses the satisfaction level of teachers of English in Preschool and Primary Education in the Principality of Asturias (Spain). The sample was composed of 238 teachers from 68 schools and the research tool was a 45-item questionnaire. Data were processed with SPSS, and variance analyses were performed to assess the impact of the variables considered. The main results confirm that general satisfaction is rather high, although it is possible to identify improvement proposals in relation to the social recognition of teaching, the professional status and the acknowledgement of the teaching activity by education authorities. In addition, the results show that age, educational stage, and administrative status influence teachers' satisfaction.
\end{abstract}

Keywords: Teacher satisfaction, English teachers, English as a Foreign Language (EFL), Preschool Education, Primary Education.

\section{Satisfacción de los maestros de inglés en Educación Infantil y Primaria en el Principado de Asturias}

\section{RESUMEN}

Este trabajo analiza la satisfacción docente de los maestros de Inglés en Educación Infantil y Primaria en el Principado de Asturias. La muestra del estudio incluye a 238 maestros de 68 centros y el instrumento de investigación fue un cuestionario de 45 ítems. Los datos obtenidos fueron procesados con SPSS y se realizaron análisis de la varianza para medir el impacto de las variables consideradas. Los principales resultados confirman que la satisfacción general de los docentes es elevada, aunque es posible identificar propuestas de mejora en relación con el reconocimiento social de la profesión, el estatus profesional, y el reconocimiento de la labor docente por parte de las autoridades educativas. Además, los resultados confirman que la edad, la etapa educativa, y el estatus administrativo tienen influencia en la satisfacción docente.

Palabras Clave: Satisfacción docente, maestros de inglés, Inglés como lengua extranjera, Educación Infantil, Educación Primaria.

\section{Introduction and research context}

This paper focuses on analyzing the satisfaction level of teachers of English as a Foreign Language (EFL) in Preschool and Primary Education in the Principality of Asturias. The study relies on prior research investigating teachers' satisfaction, especially those works devoted to exploring the satisfaction degree of teachers of Asturian language working in Preschool and Primary Education in the public schools of the Principality of Asturias (González-Riaño \& Armesto Fernández, 2012). Although teaching satisfaction, together with stress and motivation, is a recurring issue in education (Evans, 1998; Dörnyei, 2001b; Pennington, 1995; Pennington \& Ho, 1995; Troman \& Woods, 2001), research investigating teaching satisfaction in Spain is scarce and, to our best knowledge, there are no scientific publications on the satisfaction level of English teachers in Preschool and Primary Education.

The paper is especially relevant when we consider the importance of learning foreign languages in today's interconnected world, and the need to improve students' communicative competence. It is widely accepted that English is the most widespread language for international communication, although in Spain there have been concerns about the quality of language training in English in Preschool and Primary Education, stages of paramount importance in language development. According to the results of official surveys (European Commission, 2012: Eurydice, 2012) Spain consistently lags behind other European state members in the command of foreign languages, and it is

\footnotetext{
1 This paper is part of the project (details removed for peer review), selected in the call (details removed). This work is part of a larger research project funded by the
} (Agency). 
among the group of 5 countries where citizens are less likely to be able to speak a foreign language - only $18 \%$ of the population (European Commission, 2012, p. 13).

In this framework, the Spanish Government and the Government of the Principality of Asturias allocate substantial funds to improve the quality of language training in English, the effect of which is traditionally criticized by parents' associations and education communities alike. In fact, there is a widespread belief that teachers' training and language competence in English is not suitable (especially in Preschool and Primary Education), and blame is directed at English teachers to explain the poor results of students. The cause of low competence in English, however, is complex and includes other variables such as lack of linguistic immersion, the position of Spanish as one of the worlds' most spoken languages, and the continued use of dubbing instead of subtitling. Nevertheless, society's perception towards language teachers has declined over the last few years, perhaps as a need to find a straightforward explanation for the poor results in English. Although no empirical data are available, more often than not, fingers point to English teachers as one of the causes for the low performance of Spanish students in the L2; in addition, burnout in teachers of Primary Education is becoming more visible due to the poor status of educators.

Low status in the teaching profession is a perennial issue in Spain, despite numerous education reforms passed since the 1980s (Esteve, 1987). On the contrary, teaching satisfaction has dropped in the last decade in all educational stages in Spain: Anaya and López (2014) evaluated the job satisfaction of teachers of Preschool, Primary, and Secondary Education in 2013, and found a significant drop compared to a study carried out ten years ago (Anaya \& Suárez, 2006), an estimated reduction of 23\% in job satisfaction in Spanish teachers in the last decade.

The present study thus provides empirical data to facilitate a clearer picture about language learning, since there are no scientific or empirical grounds supporting some of the (negative) beliefs about the role of teachers in Spain, a field of study that remains neglected. An analysis of teachers' satisfaction can also offer relevant information about possible deficiencies in students' training in English: some of these problems may not be detected in language tests and surveys measuring language competence. Instead, by analyzing teachers' perceptions, we aim to study the situation as a whole, by including elements usually ignored in language tests, such as the use of the L2 outside the school, available resources, internationalization of schools, methodological approaches, and so on. We feel these are essential questions to ask language teachers, those on the frontline who have an informed opinion and hands on expertise.

\section{Theoretical framework: teaching satisfaction}

Scientific literature is prolific in the analysis of what motivates language learners, although the motivation of language teachers has been examined to a lesser extent, as argued by Kassabgy, Boraie and Schmidt (2001). The motivation of teachers working in several fields has also been extensively investigated (see Pennington, 1995), while that of language teachers remains relatively unexplored. Moreover, the concept of Teaching Satisfaction (TS) in the field of languages has been neglected. Consequently, this paper aims to investigate TS by addressing the opinions of educators, since an analysis of what teachers think, know, and perceive is essential to their teaching practice (Borg. 2006).
TS is a complex construct that may be difficult to define due to its ambiguous nature (Evans, 2002; Zembylas \& Papanastasiou, 2004). However, TS has been described as the "pleasant experience of psychological growth produced by high levels of quality in the teaching context, job recognition, creation of knowledge, scientific freedom, and enjoyment of the job itself" (Sáenz \& Lorenzo, 1993, p. 17); ${ }^{2}$ more recent approaches portray TS as a pleasurable emotional state resulting from the appraisal of teaching as achieving or facilitating the job values, or as the contrast between the daily life in schools and the previous expectation of teachers (Ho \& Au, 2006; Montilla, Maraver-López, Romero \& Martín, 2018; Weiss, 2002). In addition, TS may be an indicator of a teacher's psychological wellbeing and reflect whether the practitioner likes teaching (Hirschfeld, 2000). In this paper, we understand TS as the teachers' emotional and psychological state resulting from the evaluation of their work conditions and their teaching activity.

Research in the fields of language teaching and education has related TS to teacher motivation (Bernaus \& Gardner, 2008; Dörnyei, Henry, \& Muir, 2016), stress and burnout (Troman \& Woods, 2001; Vandenberghe \& Huberman, 1999), and intrinsic and extrinsic factors affecting teachers' professional satisfaction (Hirschfeld, 2000). Most studies confirm that teachers who are satisfied with their job are more motivated towards their students' academic achievement, their own teaching duties, and are more likely to consider innovation and methodological experimentation in education (Anaya \& López, 2014; Dinham \& Scott, 2000). On the other hand, dissatisfaction in teaching seems to be coupled with imposed teaching approaches, lack of academic and/or professional autonomy, unexpected changes, criticism in the media, lack of resources, and low salaries (Dinham \& Scott, 2002; Van den Berg, 2002; Vandenberghe \& Huberman, 1999).

International research has shown that TS is generally shaped by intrinsic elements - those factors related to the teaching practice, contact with students, interacting with colleagues, etc. - rather than extrinsic ones - status, payment and conditions, career prospects, etc. (Dinham \& Scott, 2002; Hirschfeld, 2000; Van den Berg, 2002; Zembylas \& Papanastasiou, 2004). Analyzing teachers of English as a Second Language, Pennington and Riley's (1991) survey in the United States found that English teachers were moderately satisfied (with emphasis on their relationship with students and colleagues), while lesser satisfaction results from opportunities for career advancement, compensation, and administrative policies and practices. Kassabgy, Boraie and Schmidt (2001) confirm the same pattern in their study in Egypt and Hawaii, and the general tendency observed is that participants prioritize internal elements (i.e. helping students, having good relationships with colleagues, and enjoying teaching) over external factors (salary, title, and job opportunities). Furthermore, this study underlines that satisfaction level varies according to the type of job, as it investigated a sample of teachers working in several educational stages, and no homogeneity was spotted in many of the answers.

In the context of the Spanish education system, no works have been devoted to the analysis of TS in English teachers. In the field of general TS, the pioneering work by Zubieta and Susinos (1992) studied the satisfaction degree of teachers, concluding that this level is related to the educational stage, ability to participate in school management, and professional promotion possibilities. Padrón (1994) analyzed TS in Secondary Education to find out that, although teachers are generally satisfied with their activity, the main focus of dissatisfaction is related to the lack

Our own translation. 
of social recognition. Cordeiro (1997) analyzed the absence of TS underlining that it may increase according to several factors: teaching subjects outside one's specialization field, and working in problematic schools. Salanova (2003) evaluated the satisfaction of Secondary Education teachers, reporting that low satisfaction is related to the intensity of teaching tasks, bad relations with parents and students, lack of cooperation with colleagues, students' low motivation, and inadequate teaching materials. Praver and Oga-Baldwin (2008) concluded that TS depends on external factors (professional autonomy, support of the school board, etc.) more than on internal elements (language competence, didactic training, etc.). As regards non-university teaching, Villanueva, Jiménez and Verdú (2003) argue that satisfaction is considerably lower in the case of female teachers, professionals working in Preschool Education, older teachers, and those working in urban schools.

González-Riaño and Armesto Fernández (2012) present research in the same thematic line to this paper: language teaching and TS. Using a satisfaction questionnaire, this study explores the satisfaction level of teachers of Asturian language in Preschool and Primary Education. The most relevant conclusions underline the positive level of satisfaction, especially as regards good relations with the education community and students' performance; conversely, low satisfaction levels result from a lack of recognition by the education authorities, problems related to professional status, and low social prestige associated to teaching.

Finally, the study of Anaya and López (2014) concludes that teachers are mostly satisfied with teaching practice, personal fulfilment, and job conditions, but are less enthusiastic about salary, promotion opportunities, and relations with education authorities. According to Anaya and López (2014), teachers of Primary Education are less satisfied than those working in Preschool Education, while general satisfaction levels decrease with more experienced teachers and female teachers are more satisfied than their male colleagues.

According to the theoretical framework and the purpose of the current study, the research objectives of this paper are the following:

1) Assess the satisfaction level of teachers of English in Preschool and Primary Education in Asturias according to intrinsic and extrinsic elements: a) general satisfaction; b) life at the school; c) academic elements; d) professional issues; e) activity planning and implementation.

2) Provide appropriate rationale to explain the possible differences (individual variables, training issues, administrative elements, etc.).

3) Establish the main educational implications derived from the conclusions of the study and provide improvement proposals.

Our main hypothesis is that TS among teachers of English in Asturias will be moderately high, although differences will be identified according to the administrative status, the age of practitioners, the educational stage, and the fact they deliver content subjects in English in bilingual streams. The rationale for our hypothesis is that research has reported that teachers are moderately satisfied as they prioritize internal elements over external factors (Kassabgy, Boraie, \& Schmidt, 2001; Anaya \& Suárez, 2007). We expect that teaching will produce a fatigue effect in more experienced teachers; likewise, teachers working in Preschool Education claim they receive less support from education authorities when it comes to materials and resources; finally, teachers in bilingual streams are likely to be less satisfied since they frequently teach non-language subjects (which is not their field of expertise).

\section{Method}

This paper relies on quantitative methodology: a survey was designed to assess the level of satisfaction of English teachers. The questionnaire was submitted to the schools, and the teachers completed it anonymously. Data were analyzed with SPSS v.24.

\subsection{Participants and procedure}

The population of the study includes all teachers of English working in public schools of Preschool and Primary Education in Asturias offering the so called bilingual streams (113 establishments out of the 198 schools of Preschool and Primary Education in the region), since we wanted to check possible differences between teachers working in mainstream and bilingual groups. In the academic year 2015-2016, 611 teachers worked in Preschool and Primary Education in public establishments in Asturias within the bilingual streams; 571 teaching English and 40 teaching non-language subjects. The selection of the participating schools obeyed to an intentional sampling process aimed to guarantee the quality and the balance of the sample, that includes urban, semi-urban and rural schools. In addition, in order to have a balanced sample, the study includes schools offering bilingual streams and regular schools. The final sample includes 238 respondents (82.8\% woman and $17.2 \%$ men) from 68 schools who answered the satisfaction survey: $54.2 \%$ of participants work in Primary Education; 5.9\% work in Preschool Education, while $39.9 \%$ teach in both stages. $50.8 \%$ teach in bilingual streams, while $49.2 \%$ of the sample work in regular. Additional details are provided in Table 1:

Table 1. Participants' characteristics.

Type of school

Age

Experience

Administrative status

\section{$57.1 \%$ urban}

$8 \%$ - 20-30 years

$35.3 \%$ less than 10 years

$66.4 \%$ civil servants
$25.6 \%$ rural

$38.2 \% 30-40$ years

$44.1 \% 10-20$ years
$17.2 \%$ semi-urban

$35.3 \%$ 40-50 years

$18.1 \%$ 20-30 years
$18.5 \%$ 50-65 years

$2.5 \%$ more than 30 years

$33.6 \%$ non-permanent teachers

\subsection{Instrument}

The research tool used in this paper is a 45-item questionnaire adapted from González-Riaño \& Armesto Fernández (2012). The questionnaire has been adapted for use in the current research by adding items that refer to the interaction of schools with foreign educational establishments, the international dimension of teachers, and other issues related to the internationalization of schools.

Respondents answered the survey according to a Likert Scale in the following format: 1-Strongly Disagree; 2-Disagree; 3Agree; 4-Strongly Agree. We intentionally used an even number 
of possible answers to avoid subjects neglecting to answer questions directly by selecting the neutral choice (Morales, Urosa and Blanco, 2003). The survey includes the following sections:

- General satisfaction ("Satisfaction" scale, items 1 to 6): professional prestige, social recognition, autonomy and teaching freedom, promotion possibilities, recognition by education authorities, etc.

- Life at the school ("School" scale, items 7 to 16): relation with the school board, parents and students, coordination with other teachers, chances of participating in the school management, etc.

- Academic and curricular issues ("Teaching" scale, items 17 to 27): language and pedagogical training of teachers, usefulness of teaching resources, methodology, etc.

- Planning of teaching activities ("Planning" scale, items 28 to 36): role and presence of English in the school language project, characteristics and nature of teaching planning, evaluation, etc.

- Perception on students' academic performance ("Performance" scale, items 36 to 45): communicative competence in English language achieved by students, literary creativity, knowledge on grammar and language issues, etc.

The tool was validated by a group of 6 experts composed of teachers of Primary Education and university lecturers (working in educational research, and English studies). Their suggestions were included in the survey, which were once again submitted for a second review; a final validation process was carried out through a pilot study with a group of teachers. The pilot stage was supported by the Kolmogorov-Smirnov test, which suggests that the sample presents a normal distribution. The reliability analyses show that Cronbach's Alpha is 0.916, which underlines that the internal consistency of the items of the questionnaire is good. Individual values of the Cronbach's Alpha per scale are shown in Table 2:

Table 2. Cronbach's Alpha according to the scales of the survey.

\begin{tabular}{lc}
\hline Scale & Cronbach's Alpha \\
Satisfaction & 0.733 \\
School & 0.693 \\
Teaching & 0.681 \\
Planning & 0.810 \\
Performance & 0.885
\end{tabular}

In addition to descriptive statistics, variance analyses (oneway ANOVA) were performed according to the scales of the questionnaire and the independent variables established in the study.

\section{Results}

First, results concerning overall teacher satisfaction are presented (first objective); results per scale will be also provided.
Next, results obtained after analyzing the independent variables established in the study will be expounded (second objective).

\subsection{General satisfaction}

Overall, it is worth mentioning that English language teachers in Asturias are generally satisfied with their teaching activity and the profession (Table 3), since mean values are higher than 2 in all the items of the scale. However, the general satisfaction of participants has to be nuanced.

Table 3. Results of teacher's general satisfaction.

\begin{tabular}{lcc}
\hline Items & Mean & SD \\
Q1-Teaching has sufficient social recognition & 2.49 & .541 \\
Q2-The professional prestige of teaching is high & 2.51 & .534 \\
Q3-There is sufficient autonomy and teaching freedom & 2.80 & .420 \\
Q4- There are enough promotion opportunities & 2.33 & .646 \\
$\begin{array}{l}\text { Q5-Teaching is appropriately recognized by education } \\
\text { authorities }\end{array}$ & 2.14 & .640 \\
$\begin{array}{l}\text { Q6- There are enough possibilities to achieve } \\
\text { professional stabilization }\end{array}$ & 2.68 & .512 \\
\end{tabular}

First, it is important to mention that teachers do not perceive that social recognition of the teaching profession is particularly high (Item 1), as the mean answer is clearly lower than most other items in the survey. Secondly, almost half of participants (47.1\%) disagree with the statement that professional prestige is high (Item 2). Furthermore, 57.1\% do not concur with the idea that career promotion is feasible (Item 4 ), with only $42.9 \%$ showing positive perceptions towards it. The recognition of the job and the role of English teachers by education authorities produced the lowest values (Item 5): $57.1 \%$ of respondents disagree, and $14.3 \%$ strongly disagree. Finally, the possibilities to have a stable teaching position (Item 6) also require some reflection, since $30.3 \%$ of teachers consider that stable positions are scarce in education.

When analyzing the mean values grouped according to the scales of the questionnaire (Table 4), the general satisfaction scale shows the lowest scores. This fact suggests that English teachers are less satisfied with extrinsic elements included in this scale, such as their social recognition, the status of language teachers, or the relationship with the education authorities.

Table 4. Mean values of the five scales in the questionnaire

\begin{tabular}{lcc}
\hline Scale & Mean & SD \\
Satisfaction & 2.49 & .36 \\
School & 2.75 & .21 \\
Teaching & 2.62 & .26 \\
Planning & 2.70 & .28 \\
Performance & 2.70 & .35
\end{tabular}

The variance analyses show that there are statistically significant differences in all the variables considered in the study with the exception of the gender of participants (Tables $5 \mathrm{a}$ and $5 \mathrm{~b}$ ): 
Table 5a. Results of variance analyses according to the independent variables

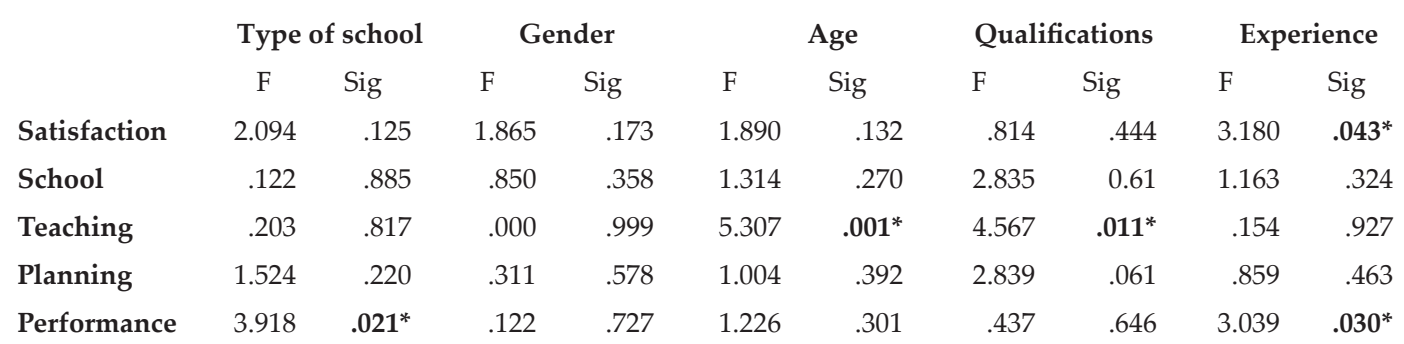

Table 5b. Results of variance analyses according to the independent variables

\begin{tabular}{lcccccccc} 
& \multicolumn{2}{c}{ English training } & \multicolumn{2}{c}{ Educational stage } & \multicolumn{2}{c}{ Administrative Status } & \multicolumn{2}{c}{ Bilingual stream } \\
& F & Sig & F & Sig & F & Sig & F & Sig \\
Satisfaction & .811 & .594 & .899 & .408 & 3.350 & $.037^{*}$ & .592 & .433 \\
School & 3.40 & $.030^{*}$ & 3.181 & $.043^{*}$ & .538 & .584 & .020 & .887 \\
Teaching & 1.293 & .248 & 3.462 & $.033^{*}$ & 3.904 & $.021^{*}$ & .029 & .864 \\
Planning & .745 & .651 & 1.100 & .334 & 1.577 & .209 & .301 & .584 \\
Performance & .750 & .648 & 1.445 & .238 & .891 & .412 & 7.636 & $.006^{*}$ \\
& & & & & & $*$ & &
\end{tabular}

\subsection{Type of school}

Schools located in rural areas have fewer possibilities to use teaching resources than schools in urban areas $(p=0.007)$. Likewise, rural schools have less interaction with foreign schools ( $p=$ 0.043). As for autonomy concerning teaching methodology and pedagogical approaches, there seems to be less flexibility in educational establishments in urban areas compared to schools in semi urban and rural areas $(p=0.017)$. This tendency can also be observed when analyzing personal autonomy and academic freedom of teachers working in urban areas ( $p=0.017)$.

Teachers of semi urban schools show a more negative perception on two elements related to students' academic performance: $60 \%$ consider that students' reading comprehension when they finish Primary Education meets the objectives set in the curriculum $(p=0.039)$, while teachers in urban schools show a better perception $(77.4 \%)$ and those in rural areas the best opinion $(84.7 \%)$. Furthermore, teachers in semi urban schools have a more negative view on the reflective knowledge on the English language of students finishing their educational stage $(p=0.004)$ : only $42.5 \%$ of teachers in semi urban schools agree compared to $67.8 \%$ in rural schools and $72.9 \%$ in urban schools.

\subsection{Age}

Teachers between 40 and 60 years are less optimistic about professional promotion than younger practitioners $(p=0.009)$. Where didactic and pedagogical training is concerned, the satisfaction degree of teachers seems to be related with the age factor). The younger the teachers, the better their perception of training received $(p=0.032)$. This tendency can also be observed as regards the perception of participants regarding the reading comprehension of their students when finishing Preschool and Primary Education $(p=0.012)$. Surprisingly, this pattern is partially reversed when considering the international teaching experience $(p=0.005)$, where younger teachers show lower satisfaction levels. Similarly, when asked about the oral comprehension of students, younger teachers report a less optimistic vision $(p=0.012)$.

\subsection{Academic background}

Teachers having more than one university degree have a more negative perception on the possibilities of professional stabilization $(p=0.005)$. It is also worth noting that teachers with 4- and 5-year degrees have more problems when coordinating with other language teachers $(p=0.007)$ : only $58.8 \%$ of teachers with a Licenciatura or Grado think the coordination is appropriate and fluent compared with $90 \%$ of teachers with 3-year degrees.

As regards didactic and pedagogical training $(p=0.001)$, teachers with 3-year degrees show less positive views $(67.1 \%$ agree) than those with 4 - or 5-year degrees (88.2\% agree) and those with a diploma plus a 4 - or 5 -year degree $(88.4 \%$ consider their training is good).

\subsection{Experience}

Our results show that the more experience teachers have, the worse their perception on career opportunities $(p=0.000)$. This tendency can also be observed in teachers' perception on recognition by the education authorities $(p=0.000)$, with teachers with more experience showing less satisfaction levels with the system.

Likewise, teachers with more experience show more positive values as regards the possibilities of professional stabilization ( $p$ $=0.002$ ). More experienced participants are also more satisfied with the possibilities to use teaching resources $(p=0.004)$.

Finally, teachers' experience also influences the perception of the communicative competence achieved by the students: more experienced teachers are more favorable towards the communication competence of students as well as their oral $(p=0.000)$ and written $(p=0.028)$ comprehension.

\subsection{Educational stage}

Statistically significant differences can also be found regarding the usefulness of textbooks according to the educational stage $(p=0.019)$, with teachers of Preschool Education showing clearly 
worse attitudes (only $40 \%$ consider textbooks useful) than their counterparts in Primary Education (90\% think textbooks useful).

The same tendency is repeated in the suitability of the curriculum of English language in the educational stage $(p=0.028)$, with teachers of Preschool Education again showing a more negative perception. In fact, teaching in Preschool Education seems to be a hurdle in order to take part in seminars and courses on new educational approaches $(p=0.001)$, since $85.8 \%$ of participants think they have few or very few possibilities to further their training, something which is shared amongst $26.3 \%$ of teachers of Primary Education and $46.3 \%$ of teachers working in both educational stages.

Similarly, when asked if students' reading comprehension when finishing the educational stage meets curriculum standards $(p=0.000), 84.8 \%$ of teachers of Primary Education answer positively, greater than the $42.9 \%$ of teachers working in Primary Education and $69.9 \%$ working in both educational stages. Results are also similar as regards written expression ( $p=0.005): 64.8 \%$ of teachers of Primary Education consider students' written expression meets the curriculum standards compared to $58.1 \%$ working in both stages and $42.9 \%$ working in Preschool Education.

\subsection{Specific training in English language}

The training of English teachers may also have an impact on teaching satisfaction. Clearly $(p=0.001)$, teachers with only a degree in Education report that professional promotion opportunities are sufficient $(57.8 \%)$ compared to those with further training in English language. Furthermore, teachers who have more specific training in English show a better perception on the coordination with other language teachers $(p=0.010)$, the possibilities to take part in the management of the school $(p=0.002)$, and the possibilities to engage in international projects $(p=0.010)$.

Finally, teachers with more specific training are more positive towards the use of textbooks in their classes $(p=0.000)$, and the attitude of students towards their teachers $(p=0.000)$.

\subsection{Administrative situation}

The administrative situation renders statistically significant differences as regards the social recognition of teaching ( $p=$ 0.000 ), which is high for $71.4 \%$ of temporary workers, $66.7 \%$ of state workers with a definite school, and $41.1 \%$ who are state workers but teach in a temporary school.

When asked about the recognition of the education authorities $(p=0.002)$, state workers in a definite school again show less positive values, as only $23.4 \%$ consider there is a high recognition, compared to $37.7 \%$ of temporary teachers and $66.7 \%$ of state workers teaching on a temporary basis.

Finally, temporary workers are clearly more negative as regards students' communicative competence in English ( $p=$ 0.008 ): only $50 \%$ consider students' competence high, against $72.3 \%$ of state workers with a definite destination and $100 \%$ of civil servants working on a temporary basis.

\subsection{Teachers working in bilingual streams}

Statistically significant differences were found regarding teachers' relationship with the school board $(p=0.020)$ and with other teachers in the school $(p=0.035)$ : in both cases, teachers working in bilingual streams show slightly more negative values about school integration (although we must note that it is still very positive). Teachers in bilingual sections are also more reluctant concerning the autonomy to choose teaching methodology and approaches as well as materials and resources to be used ( $p$ $=0.048$ ).

As for the communicative competence achieved by the students, statistically significant differences can be clearly seen ( $p$ $=0.000$ ), with teachers in bilingual streams rendering the most positive results.

Finally, it is worth mentioning that students in bilingual streams are more conscious of the importance of learning English today than pupils in mainstream schools $(p=0.013)$. Similarly, reflective knowledge on grammar and metalinguistic questions are higher for teachers in bilingual streams $(p=0.017)$.

\subsection{Teachers' perception on students' performance}

The overall perception of practitioners is good according to the results of the scale "Performance" (mean = 2.7055). It is interesting to note that $57.8 \%$ of surveyed teachers think the oral production and reception skills of the students are appropriate when they finish Primary Education and they meet the criteria and standards included in the curriculum in this field. However, it is worth mentioning that teachers emphasize that they do not consider their students use English independently and frequently outside the classroom: this statement is supported by $77 \%$ of participants.

\section{Discussion}

Teaching satisfaction of teachers of English in Preschool and Primary Education in Asturias seems to be high in general terms. However, according to the results of this study it must be emphasized that teachers demand stronger efforts by education authorities to recognize their teaching activity and value the profession, as many participants do not perceive that they enjoy the professional prestige and the stabilization possibilities they deserve. This conclusion compares favorably with previous research such as Karavas (2010), González-Riaño \& Armesto Fernández (2012), and Anaya and López (2014).

In this sense, this study also confirms that, in the particular case of teachers of English in the Principality of Asturias, we find that intrinsic factors are more valued by practitioners than extrinsic ones (Dinham \& Scott, 2002; Hirschfeld, 2000; Pennington \& Riley, 1991; Van den Berg, 2002; Zembylas \& Papanastasiou, 2004). This conclusion can be interpreted as an indicator of teachers' commitment towards their teaching practice, as practitioners show high levels of satisfaction despite their expectations regarding external factors not being met, such as status and compensation. Scientific literature supports that motivation is a principal determinant of language learning and that the behavior of language teachers in the classroom can affect students' performance (Dörnyei, 2001a). According to the results of the present study, EFL teachers are satisfied with their job and show good levels of intrinsic motivation towards their teaching activity; therefore, it can be argued that these attitudes may create positive learning contexts in the classroom. As a result, the social vision on the role and performance of teachers of English in Asturias might not be accurate and should be reconsidered.

Internationalization, together with the possibilities to participate in lifelong learning and innovation initiatives, have been identified as elements where improvement proposals should be designed according to the participant teachers, who consider that the interaction with foreign schools as well as their international dimension (i.e., teaching experience and training) should be more intense. Indeed, according to our study, authorities should promote the reinforcement of the contact of public schools in 
Asturias with national and international establishments aiming to provide teachers with opportunities to participate in international projects. In a nutshell, schools should promote the international dimension of teachers to improve their professional, pedagogical, and teaching profiles improving their teaching activity. This had not been previously identified as a key indicator of teachers' satisfaction and motivation; however, we feel that, in the case of language teachers, this factor has recently gained importance and will continue to do so in a more globalized world, and thus language teachers have to interconnect more with other colleagues, schools, and contexts.

The survey has also helped detect a weakness as regards language use: students do not use English on a regular basis outside of school in Primary Education. At this point, it is worth repeating that in Spain there is not a solid tradition of using English outside educational contexts. Nonetheless, it could be argued that lack of immersion contributes to the lower level of English of students of Preschool and Primary Education. In fact, the lack of exposure to English outside the schools is consistently identified by the participants of this study as a major hurdle for students to achieve optimal language competence. Again, the overarching belief in Spanish and Asturian society on the role of teachers in developing poor language competence of students should be carefully reviewed, as no evidence has been provided for that claim thus far.

Several of the variables explored in this study have proven to have some degree of influence in teaching satisfaction. The fact that TS may vary according to several factors confirms the tendency pinpointed by Kassabgy, Boraie and Schmidt (2001) and Anaya and Suárez (2007). The variables influencing teaching satisfaction in the current research are: age and experience, administrative status, educational stage, and the participation of teachers in bilingual streams.

A) Age and experience: this study has shown a relation between age / teaching experience and teaching satisfaction, with older and more experienced teachers showing less satisfaction. This is in line with the only studies assessing teaching satisfaction nationwide in Spain (Anaya \& Suárez, 2006, 2007; Anaya \& López, 2014). This could suggest fatigue or attrition that also affects language teachers. The decrease in teaching satisfaction can be triggered by several factors: a) more experienced teachers do not see that their career expectations have been met, which leads to a lack of enthusiasm towards teaching; b) extrinsic factors tend to be more relevant when modelling satisfaction over a longer period, and c) younger teachers have received more updated and solid training and more opportunities to complete their profiles.

B) Administrative status: the administrative situation of participant teachers also reveals important differences, as temporary workers especially place a more optimistic value on the teaching profession, its recognition, and prestige. This approach is not shared by civil servant, contrasting with the results of the study of González-Riaño \& Armesto Fernández (2012). A possible explanation for this is that the growing importance of English in Spain can contribute to guarantee their stabilization as teachers in the future.

C) Educational stage: teachers working in Preschool Education consistently show less positive opinions as regards their teaching activity and conditions than teachers in Primary Education (as noted by Anaya \& López, 2014) and those working in both educational stages: they consider textbooks and resources less useful and have more difficulties to participate in lifelong learning and to improve their teaching training. Likewise, they are also more skeptical about the suitability of these materials to the curriculum, in line with the research of Salanova (2003). Accordingly, it is essential for education authorities in Spain to provide professionals teaching English at early stages with more support to enlarge their training and handle specific materials and resources. It is also the duty of universities to provide specialized training for teachers of English in Preschool Education, as this subject has been largely ignored.

D) Bilingual schools: teachers working in bilingual streams are less satisfied as regards their integration at the school and their freedom to choose pedagogical approaches. This may follow from the recent implementation of bilingual streams in many schools in Asturias; also, language specialists (and not content-teachers) are teaching non-language subjects in bilingual streams, which may decrease their self-confidence. All in all, our study provides positive data as regards students' performance in bilingual streams: according to our study, students learning through English have better language competence and show stronger metalinguistic skills.

\section{Conclusions}

This study contributes to the field of language teaching and education, as the perceptions and beliefs of EFL teachers demand further research. The paper reports on empirical data on teachers of Preschool and Primary Education, and can help identify the main problems faced by teachers today and the possible sources of dissatisfaction. Far from being a minor issue, this point is extremely relevant in a country with poor rates of foreign language command.

In accordance with the generic panorama presented in this study, it can be concluded that the overall satisfaction level of the participating teachers is rather good, with intrinsic elements being perceived more favorably than external ones. To this regard, education authorities in the region should design feasible action plans to allow teachers of EFL to participate in international projects that improve their professional competence from the linguistic and pedagogical point of view. The education authorities in the region are expected to value the role of teachers of English in order to recognize the prestige of their teaching activity and contribute to the improvement in the relationship with the families, students, and institutions to promote the self-esteem and teaching satisfaction of all professionals working in Preschool and Primary Education.

Finally, the possible limitations of the current paper must be mentioned. It is a quantitative study exploring the current situation of teachers of English in Asturias and provides generic data on teaching satisfaction. Therefore, the results of the study should be taken with caution and further analysis and research should be conducted, especially using qualitative approaches (classroom observation, interviews, discussion groups, etc.). In addition, teaching satisfaction is difficult to measure and quantify, and results can vary among different clusters or groups of teachers. However, we feel that teaching satisfaction is a field that demands further investigation following different paradigms, approaches, and research methodologies in education.

\section{Reference list}

Anaya Nieto, D., \& López Martín, E. (2014). Spanish teachers' job satisfaction in 2012-13 and comparison with job satisfaction in 2003-04. A nationwide study. Revista de Educación, 365, 96-121. http://www.mecd.gob.es/dctm/revista-de-educacion/articulos346/061.satisfaccioc2bfc3bcnlaboralrev.ed.365. 
pdf?documentId=0901e72b819f0eb7. doi: 10.4438/1988-592XRE-2014-365-266

Anaya Nieto, D., \& Suárez Riveiro, J. M. (2006). La satisfacción laboral de los profesores en función de la etapa educativa, del género y de la antigüedad profesional. Revista de Investigación Educativa, 24(2), 541-556. http://revistas.um.es/rie/article/ viewFile/97181/93311

Anaya Nieto, D., \& Suárez Riveiro, J. M. (2007). Job satisfaction of Spanish teachers in preschool, primary and secondary education levels. A study within the national scope. Revista de Educación, 344, 217-243. http://www.revistaeducacion.mec. es/re344/re344_09.pdf

Bernaus, M., \& Gardner, R. C. (2008). Teacher motivation strategies, student perceptions, student motivation, and English achievement. The Modern Language Journal, 92, 387-401. DOI: $10.1111 / \mathrm{j} .1540-4781.2008 .00753 . x$

Borg, S. (2006). Teacher cognition and language education. New York: Continuum.

Cordeiro, J. (1997). Prevalencia del síndrome de burnout en los maestros de primaria de Chiclana de la Frontera. Cádiz: University of Cádiz (unpublished report).

Dinham, S., \& Scott, C. (2000). Moving into the third, outer domain of teacher satisfaction. Journal of Educational Administration, 38(4), 379-396.

Dinham, S., \& Scott, C. (2002). The international teacher 2000 project: an international study of teacher and school executive satisfaction, motivation and health in Australia, England, USA, Malta and New Zealand. Paper presented at the Challenging Futures Conference, 2002, University of New England, Armidale.

Dörnyei, Z. (2001a). New themes and approaches in second language motivation research. Annual Review of Applied Linguistics, 21, 43-59.

Dörnyei, Z. (2001b). Teaching and researching motivation. Harlow, England: Longman.

Dörnyei, Z., Henry, A., \& Muir, C. (2016). Motivational currents in language learning: Frameworks for focused interventions. New York: Routledge.

Esteve, J. M. (1987). El malestar docente. Barcelona: Laia.

European Commission. (2012a). Europeans and their languages. Special Eurobarometre 386. http://ec.europa.eu/public_opinion/archives/ebs/ebs_386_en.pdf

Eurydice. (2012). Key data on teaching languages at school in Europe. http://eacea.ec.europa.eu/education/eurydice/documents/ key_data_series/143EN_HI.pdf

Evans, L. (1998). Teacher morale, job satisfaction and motivation. London: Paul Chapman.

Evans, L. (2002). What is teacher development? Oxford Review of Education, 28(1), 123-137.

González-Riaño, X. A., \& Armesto Fernández, X. (2012). Enseñanza de la Lengua Minoritaria y Satisfacción del Profesorado: el Caso de Asturias, Cultura y Educación, 24(2), 219-241.

Hirschfeld, R. R. (2000). Does revising the intrinsic and extrinsic subscales of the Minnesota satisfaction questionnaire short form make a difference? Educational and Psychological Measurement, 60, 255-270.

Ho, C. L., \& Au, W. T. (2006). Teaching satisfaction scale: Measuring job satisfaction of teachers. Educational and Psychological Measurement, 66, 172-185.
Karavas, E. (2010). How satisfied are Greek EFL teachers with their work? Investigating the motivation and job satisfaction levels of Greek EFL teachers. Porta Linguarum, 14, 59-78. http://www.ugr.es/ portalin/articulos/PL_numero14/4\%20 How \%20Satisfied \%20are\%20Greek\%20EFL\%20Teachers_E\%20Karavas.pdf

Kassabgy, O., Boraie, D., \& Schmidt, R. (2001). Values, rewards, and job satisfaction in ESL/EFL. In Z. Dörnyei and R. Schmidt (Eds.), Motivation and second language acquisition (Technical report 23, pp. 213-237). Honolulu: University of Hawai'i, Second Language Teaching and Curriculum Centre.

Montilla Coronado, M. V. C., Maraver-López, P., Romero Oliva, C., \& Martín Montilla, A. (2018). Análisis de las expectativas del profesorado novel sobre su futura labor docente. Aula Abierta, 47(2), 185-192. https://www.unioviedo.es/reunido/ index.php/AA/article/view/12719/11687

Morales, P., Urosa, B., \& Blanco, A. (2003). Construcción de escalas de actitudes tipo Likert: una guía práctica. Madrid: La Muralla.

Padrón Hernández, M. (1994). Satisfacción profesional del docente. Unpublished PhD thesis, University of La Laguna.

Pennington, M. C. (1995). Work satisfaction, motivation and commitment in teaching English as a second language. New York: ERIC Cleaering house (ERIC no. ED404850).

Pennington M. C., \& Ho, B. (1995). Do ESL educators suffer burnout? Prospect, 10, 41-53.

Pennington, M. C., \& Riley, P. V. (1991). A survey of job satisfaction in ESL: ESL educators respond to the Minnesota Satisfaction Questionnaire. University of Hawai'i Working Papers in ESL, 10(1), 37-56.

Praver, M., \& Oga-Baldwin, W. (2008). What motivates language teachers: investigating work satisfaction and second language pedagogy. Polyglossia, 14, 137-150.

Sáenz, O., \& Lorenzo, M. (1993). La satisfacción del profesorado universitario. Granada: University of Granada.

Salanova, M. (2003). Burnout en profesores de enseñanza secundaria: un estudio longitudinal. In I. Martínez, M. Salanova, S. Llorens, M. García, R. Grau \& E. Cifre, (Eds.), La enseñanza y el burnout: ¿una simbiosis irreversible (pp. 79-93). Castellón: Colección Psique.

Troman, G., \& Woods, P. (2001). Primary teachers stress. London: Routledge Falmer.

Van den Berg, R. (2002). Teachers' meanings regarding educational practice. Review of Educational Research, 72, 577-625.

Vandenberghe, R., \& Huberman, A. M. (1999). Understanding and preventing teacher burnout. Cambridge University Press: Cambridge.

Villanueva, M., Jiménez, I., \& Verdú, R. (2003). Satisfacción laboral en personal docente. 1st European Conference on Risk Prevention, 2003, Madrid, 12-14 February.

Weiss, H. M. (2002). Deconstructing job satisfaction: Separating evaluations, beliefs and affective experiences. Human Resource Management Review, 12, 173-194.

Zembylas, M., \& Papanastasiou, E. (2004). Job satisfaction among school teachers in Cyprus. Journal of Educational Administration, 42(3), 357-374. http://dx.doi.org/10.1108/09578230410534676.

Zubieta, J., \& Susinos, T. (1992). La satisfacción e insatisfacción de los enseñantes. Madrid: CIDE. 